\title{
Potential Use of Water Associated with Conventional Oil Production and Sea Water as Base Fluids for Hydraulic Fracturing Operations: Effect of Water Chemistry on Crosslinking and Breaking Behaviors of Guar Gum-Based Fracturing Fluid Formulations
}

\author{
Dayanand Saini ${ }^{1} \&$ Timea Mezei $^{1}$ \\ ${ }^{1}$ Department of Physics and Engineering, California State University, Bakersfield, CA, USA \\ Correspondence: Dayananad Saini, 64 SCI, 9001 Stockdale Highway, Bakersfield, CA, 93311, USA. \\ Tel: 1-661-654-2845. E-mail: dsaini@csub.edu
}

Received: April 26, 2016

Accepted: May 10, 2016

Online Published: May 20, 2016

doi:10.5539/eer.v6n1p31

URL: http://dx.doi.org/10.5539/eer.v6n1p31

The research is partially financed by mini grant provided by the Research Council of the University (RCU), California State University, Bakersfield (CSUB).

\begin{abstract}
Even though water consumption per hydraulic fracturing (or fracturing) job is relatively low; nearly all of the fresh water used for fracturing in California is in the regions of high water stress such as San Jouquin and Los Angeles Basins. However, water availability should not be a concern as huge volumes of water are being produced along with oil and gas from conventional formations (i.e. associated water) in the Kern County of California, a region where most of the fracturing activities take place. This associated water can potentially be used for preparing fracturing fluids in stimulating the unconventional formations. The present study reports on the relevant investigation done in this area of interest.

The results suggest that associated water chemistry has limited effect on the viscosity of cross-linked formulations. However, guar gum concentration was found to affect the breaking behaviors of cross-linked fracturing fluid formulations. The new type of commercially available biodegradable breaker was found to be effective in breaking the tested cross-linked formulations at elevated temperature which was as high as $85^{\circ} \mathrm{C}$ $\left(185^{\circ} \mathrm{F}\right)$.

Both crosslinking and breaking behaviors of fracturing fluid formulations evaluated in this study were found comparable to the behaviors of commonly used cross-linked formulation (guar gum $+2 \%$ potassium chloride). These results suggest that both the associated water (i.e. water resulting from regional conventional oil production activites) and sea water (offshore oil fields) could serve as alternative sources of base fluid for use in fracturing jobs without putting significant burden on precious regional fresh water resources.
\end{abstract}

Keywords: hydraulic fracturing, fresh water, guar gum-based fracturing fluid formulation, cross-linked fracturing fluid formulations, biodegradable breaker

\section{Introduction}

\subsection{Hydraulic Fracturing in California and Water Use}

Despite the fact that current Monterey shale accounts for a small fraction $(\sim 7 \%)$ of California's annual oil production, it may continue to produce significant shale oil in future as new oil extraction technologies like fracturing involve further. However, any near future exploitation of California's Monterey shale oil resource largely depends on the availability of water for fracturing jobs. A typical fracturing job in California requires around 0.5 acre-ft of water (CA FRACKFACTS website, 2015) which will translate into the need of thousands of acre- $\mathrm{ft}$ of fresh water annually for any near future development of Monterey Shale resource at large scale.

In case of California, almost all of the hydraulically fractured wells (96\%) since 2011 are in regions with high or extremely high water stress (Freyman, 2014). The total amount of water used in the 568 fracturing operations was around 202 acre-ft as reported in 2012 (Factsheet by Western States Petroleum Association (WSPA), 2015) 
which has slightly increased to 214 acre-ft in 2014 (Carroll, 2015). According to a recent report undertaken for the Bureau of Land Management concerning well stimulation in California by California Council on Science and Technology (CCST), Lawrence Berkeley National Laboratory (LBNL), and Pacific Institute (CCST et al., 2014), the upper estimate of current annual water demand for well stimulation jobs (mainly fracturing) in California is 1,200 acre-feet, based on estimates of water use from notices filed with the Division of Oil, Gas \& Geothermal Resources (DOGGR) of California Department of Conservation); the lower estimate is 450 acre-feet based on water volumes reported voluntarily to FracFocus. Ninety-five percent of water currently used in fracturing jobs is fresh water (CCST et al., 2014). It is worth to mention here that $97 \%$ of the reported fracturing jobs in California took place in Kern County, which is a part of San Joaquin Basin.

The San Joaquin Basin, a geologic province that is largely known for its conventional oil and gas production, contains a total of 21,322 fracturing treatment records associated with wells drilled from 2000 to 2010 (Gallegos \& Varela, 2015). On the other hand, conventional oil production operations in Kern County, where most of the current fracturing activities are taking place, also contributes significant volumes of water, termed here as "associated water", to the bulk of the California's oil production (67\% or 249,500 acre-ft in 2014, based on online production database of the Division of Oil, Gas \& Geothermal Resources (DOGGR) of California Department of Conservation). Though chemical composition of associated water varies from field to field (CCST et al., 2014), a possibility to use the associated water, instead of fresh water, could potentially boost fracturing capabilities in water stressed regions of California. For this, a systematic investigation on the use of associated water for preparing cross-linked guar gum-based fracturing fluid formulations and the study of breaking behavior of such formulations at elevated downhole temperature conditions is necessary. The similar investigation is warranted for using sea water for fracturing jobs in oil fields located in state waters off the Coast of Santa Barbara County.

The present study reports the results from the relevant investigations. It is noted here, a fracturing job itself results in significant water production consisting of both flow-back (i.e. water used for preparing fracturing fluid formulation) and the formation water. This water may (Mantell, 2011; Wasylishen \& Fulton, 2012; EOG Resources website, 2015) or may not be used again in new or re-fracturing jobs. However, our study is only limited to explore the potential use of associated water in preparing guar gum-based fracturing fluid formulations.

\subsection{Guar Gum-Based Fracturing Fluid Formulations}

Guar gum, a natural powder derived from the guar plant, is one of most frequently reported additive ingredient that is used as a gelling (or thickening) agent to increase the viscosity of fracturing fluid formulations. Guar plant is commonly grown in India and Pakistan, and occasionally in the United States of America (Pike, 2003). As stated by Vo, Sparks, Parton, Cortez \& Tanner Green (2014), guar-based fracturing fluids have historically been the fluid of choice because of their reliable and flexible chemistry, as well as the incentive from the economical aspect. According to a recent analysis of hydraulic fracturing fluid data from the FracFocus Chemical Disclosure Registry 1.0 reported by U.S. EPA, (U.S. EPA, 2015), typical concentrations of guar gum in fracturing fluid formulations used in oil wells across the U.S. range from $0.027 \%$ by mass (5th percentile) to $0.43 \%$ by mass (95th percentile) whereas, in case of gas wells, typical concentrations varied from $0.00057 \%$ by mass (5th percentile) to $0.38 \%$ by mass ( 95 th percentile).

In case of California, fracturing is primarily performed with gels, and the gels are predominantly cross-linked formulations mainly prepared from guar gum (included in $96 \%$ of the fracturing jobs), a gelling agent, and borate compound (included in $90 \%$ of the fracturing jobs), which serves as cross-linker (Long et al., 2015). Typical concentrations of guar gum in fracturing fluid formulations used in oil wells located in Kern County range from $0.11 \%$ by mass (5th percentile) to $0.34 \%$ by mass (95th percentile) (U.S. EPA, 2015). In general, guar concentrations of $0.12-0.96 \%$ by mass have been reportedly used for fracturing operations (Robert and Pin, 1993 in Barati \& Liang, 2014; Al-Kanaan, Rahim, \& Al-Anazi, 2013).

For preventing swelling and migration of formation clays, potassium chloride $(\mathrm{KCl})$ is added to the base fluid. $\mathrm{KCl}$ is typically added at a concentration of $2 \%$ but can be added at concentrations as high as $8 \%$ depending on laboratory testing results (Montgomery, 2013). According to Pike (2003), Guar is capable of hydrating in many different types of water (i.e. forming a high viscosity solution). It is capable of tolerating sodium chloride $(\mathrm{NaCl})$ and potassium chloride $(\mathrm{KCl})$ up to $5 \%$ by weight and is also compatible with polyvalent metal (calcium, magnesium, aluminum) ions. The optimal $\mathrm{pH}$ range for hydration of guar is 6.5-7.5, but it hydrates even at a higher or a lower $\mathrm{pH}$ at an inhibited rate (Pike, 2003).

As mentioned earlier, ninety-five percent of water currently used in fracturing jobs in California is fresh water. If, 
associated water or sea water were to be potentially used as base fluid, the effect of their chemical composition (i.e. presence of various ions) on guar gum's crosslinking behavior at elevated temperature needs to be investigated first. This forms the first objective of present study.

\subsection{Degradation of Cross-Linked (Guar Gum-Based) Fracturing Fluid Formulations}

After fracturing job (i.e. pumping of cross-linked fracturing fluid formulation carrying desired amount of proppant for fracturing of the formation) is successfully completed, proppant pack placed in newly created fractures requires cleanup for allowing fractures and formation to flow. This is achieved by breakers which are added to fracturing fluid formulation during pumping and remain inactive during the fracturing job. When pumping stops, they rapidly break the cross-linked fracturing fluid formulation and reduce its viscosity in order to release proppant into fractures. The residual fracturing fluid is then removed (but not the proppant) by producing the well.

The three general types of breakers are Oxidizers, Acid, and Enzymes (Montgomery, 2013). Montgomery (2013) has discussed the advantages and disadvantages of above mentioned types of breakers. Peroxydisulfuric acid, diammonium salt and proprietary chemicals (e.g. cured acrylic resin) are among frequently reported additive ingredients that are listed in U.S. EPA report (U.S. EPA, 2015) as breakers (or breaker catalysts). According to Halliburton Energy Services (in Kyaw, Azahar, \& Tunio, 2012), selection of a particular breaker type depends on its performance the temperature, $\mathrm{pH}$, time, and desired viscosity profile for each specific treatment however enzyme based breakers, due their biological origin, are considered more environmentally friendly.

Though, enzyme based breakers break guar polymers more efficiently and leave fewer residues compared with oxidizers they are highly temperature and $\mathrm{pH}$ sensitive (Barati and Liang, 2014) and may require too much time to break the pumped fracturing fluid. Recent advancements in biotechnology field have enabled scientists to develop enzyme based breakers that provide the advantage of leaving low residue in the fracture, improve the fracture permeability, and improve the efficiency of water-based fracturing stimulation while being high temperature resistant, acid and alkali resistant ( $\mathrm{pH}$ range of 3 to 10), and salt resistant (Qingdao Lead Oilfield Solutions Co., Ltd (Refer to as L.E.A.D.) website, 2015). However, their suitability and especially the breaking behavior over time needs to be tested for degrading guar gum-based fracturing fluid formulations prepared using associated water or sea water as base fluids. This is the second objective of the present study.

\section{Materials and Procedures}

To study the effect of water chemistry of associated water on guar gum-based fracturing fluid formulations' cross-linking and breaking behaviors, publically available associated water's chemical composition data for local oilfields (online associated water chemical analysis database available on DOGGR website) were collected and analyzed. Based on the analysis, two base (associated) water compositions (Brine E which is representative of associated water typically produced from EastSide oilfields (Figure 1) and Brine $\mathrm{H}$ which is representative of associated water typically produced from WestSide oilfields (Figure 1)) were chosen for preparing fracturing fluid formulations.

The constituents and their concentrations of chosen base (associated water and sea water) fluids are given in Table 1. As per their concentrations (Table 1), various salts (Table 2) were dissolved in deionized water for preparing synthetic base fluids in the laboratory. As can be seen from Table 2, Brine $\mathrm{H}$ is quite saline (total dissolved solids (TDS) of 45,968 parts per million (ppm)) whereas Brine E has a nearly "fresh water" composition (a low TDS of 1089 (ppm)). It is worth to mention here that majority of recent fracturing jobs in Kern County has been reported to occur in the vicinity of WestSide oilfields where associated water is quite saline (i.e. similar to Brine H). Apart from Brines E and H, 2\% potassium chloride $(\mathrm{KCl})$ solution $(20,000 \mathrm{ppm}$ TDS) and a typical sea water composition (38,752 ppm TDS) were two other compositions that were used as base fluid.

In view of the fact that guar gum concentration in water-based fracturing fluid formulations reported in published literature vary significantly, five guar gum concentrations equivalent to $0.30 \%$ by mass (equivalent to $25 \mathrm{lbs}$ guar/ 1000 gallons of water), $0.42 \%$ by mass (equivalent to $35 \mathrm{lbs}$ guar $/ 1000$ gallons of water), $0.54 \%$ by mass (equivalent to $45 \mathrm{lbs}$ guar/1000 gallons of water), $0.65 \%$ by mass (equivalent to $55 \mathrm{lbs}$ guar/1000 gallons of water), and $0.84 \%$ by mass (equivalent to $70 \mathrm{lbs}$ guar $/ 1000$ gallons of water) were selected for covering the typically used range of guar gum concentrations in typical water-based fracturing fluids.

The various materials and laboratory procedures used for achieving study's objectives are briefly discussed next. 


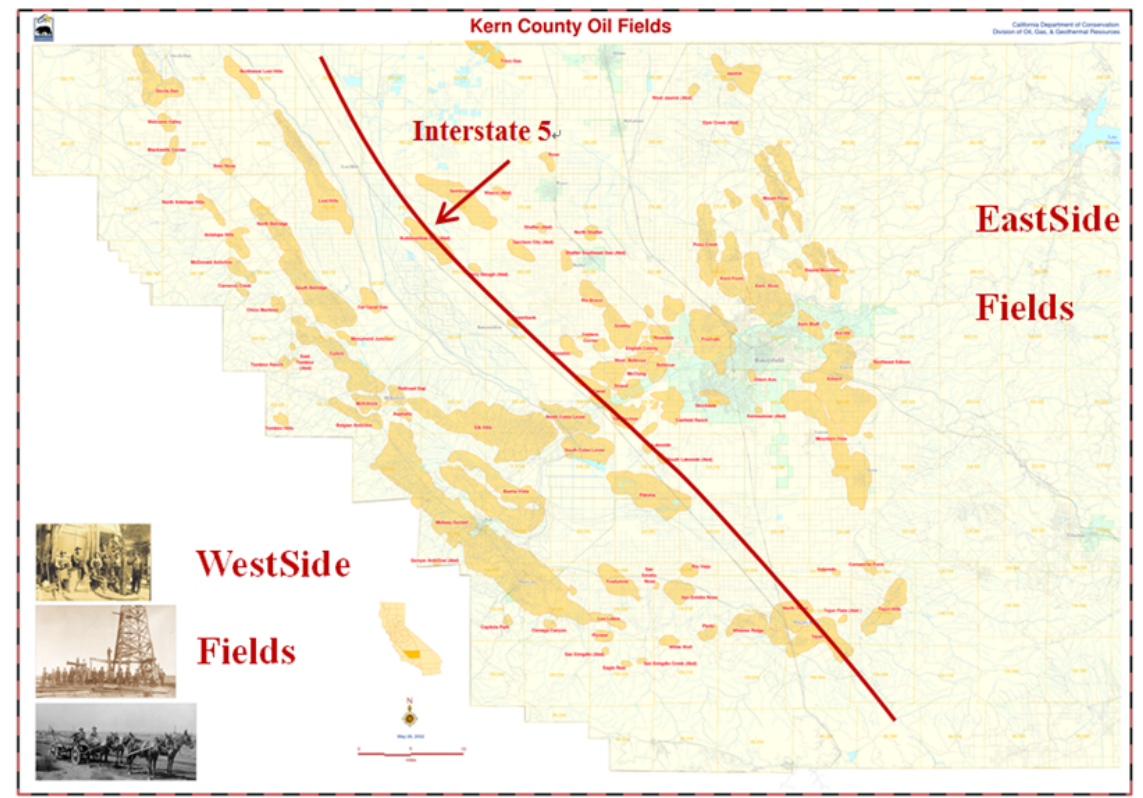

Figure 1. Kern County (California) oil fields (EastSide and WestSide), modified from oilfield location map available at DOGGR website

Table 1. Chemical compositions of associated water (Brines $\mathrm{E}$ and $\mathrm{H}$ ) and sea water used as base fluids

\begin{tabular}{lllll}
\hline Ion & Concentration & Brine E & Sea Water & Brine H \\
\hline Bromide $(\mathrm{Br}-1)$ & $\mathrm{g} / 1$ & - & 66.9 & - \\
Sulfate $(\mathrm{SO} 4-2)$ & $\mathrm{g} / 1$ & 54.0 & 2666.6 & 1.4 \\
Sodium $(\mathrm{Na}+1)$ & $\mathrm{g} / 1$ & 280.0 & 11232.0 & 12720.0 \\
Potassium $(\mathrm{K}+1)$ & $\mathrm{g} / 1$ & 12.0 & 371.6 & 102.0 \\
Magnesium $(\mathrm{Mg}+2)$ & $\mathrm{g} / 1$ & 1.7 & 1447.7 & 614.0 \\
Calcium $(\mathrm{Ca}+2)$ & $\mathrm{g} / 1$ & 41.0 & 423.0 & 2034.0 \\
Bicarbonate $(\mathrm{HCO}-1)$ & $\mathrm{g} / 1$ & 160.0 & 121.0 & 146.0 \\
Boron $(\mathrm{B}+1)$ & $\mathrm{g} / 1$ & - & 4.4 & 16.7 \\
Strontium $(\mathrm{Sr}+2)$ & $\mathrm{g} / 1$ & - & 6.2 & 30.0 \\
\hline
\end{tabular}

Table 2. Amounts of different salts dissolved in deionized water for preparing base fluids

\begin{tabular}{|c|c|c|c|c|}
\hline Salt & $2 \% \mathrm{KCl}(\mathrm{g} / \mathrm{l})$ & Brine E $(g / l)$ & Sea Water $(\mathrm{g} / \mathrm{l})$ & Brine H $(g / l)$ \\
\hline $\mathrm{KCl}$ & 20.00 & 0.02 & 0.68 & 0.19 \\
\hline $\mathrm{NaCl}$ & - & 0.50 & 24.12 & 32.86 \\
\hline $\mathrm{KBr}$ & - & - & 0.10 & - \\
\hline $\mathrm{NaF}$ & - & - & 0.00 & - \\
\hline $\mathrm{CaCl}_{2} \cdot 2 \mathrm{H}_{2} \mathrm{O}$ & - & 0.15 & 1.55 & 7.46 \\
\hline $\mathrm{MgCl}_{2} \cdot 6 \mathrm{H}_{2} \mathrm{O}$ & - & 0.01 & 12.11 & 5.14 \\
\hline $\mathrm{B}(\mathrm{OH})_{3}$ & - & 0.00 & 0.00 & 0.02 \\
\hline $\mathrm{SrCl}_{2} \cdot 6 \mathrm{H}_{2} \mathrm{O}$ & - & - & 0.02 & 0.09 \\
\hline $\mathrm{BaCl}_{2} \cdot 2 \mathrm{H}_{2} \mathrm{O}$ & - & - & - & - \\
\hline $\mathrm{Na}_{2} \mathrm{SO}_{4} \cdot 10 \mathrm{H}_{2} \mathrm{O}$ & - & 0.18 & - & 0.00 \\
\hline $\mathrm{NaHCO}_{3}$ & - & 0.22 & 0.17 & 0.20 \\
\hline Total Dissolved Solids (TDS) in $\mathrm{g} / \mathrm{l}$ & 20.00 & 1.09 & 38.75 & 45.97 \\
\hline
\end{tabular}

\subsection{Synthetic Base Fluids}

All four base fluids used in the study for evaluating the effect of water chemistry on guar gum-based fracturing fluid formulations were synthetically prepared in the laboratory. For this, calculated amounts of salts (Table 2) were dissolved into deionized water for representing various ionic constituents as per their concentrations in 
specific base fluid. The $\mathrm{pH}$ values of synthetic base fluids at room temperature were measured using a digital $\mathrm{pH}$ meter.

\subsubsection{Pre-Crosslinking Hydration and Viscosity Measurements}

For this, a glass beaker containing 200 milliliters (mL) of a chosen base fluid was placed on a stirring plate. Chosen guar gum concentration was mixed in the brine using a strainer to insure an even distribution and avoid clumps. A magnetic stirrer was placed in beaker for facilitating initial hydration of guar gum in base fluid. The solution was then left to mix for 2-5 minutes on the stirring plate, and then placed in a commercial electric blender and blended for 2 minutes for achieving complete hydration between guar and base fluid. Hydrated solution was poured back into the glass beaker where any apparent foams generated during mixing were allowed to settle. Any observed foams can also be removed from the top manually using a spatula. The viscosity of solution was measured at room temperature using a digital rotational viscometer. Viscosity was recorded at three different speeds of 60,300 , and 600 rounds per minute (RPM). The corresponding shear rates to the used speeds are given in Table 3. Viscosity measurements were repeated three times to ensure quality data and consistency of measurements. The $\mathrm{pH}$ of prepared solutions was measured using a digital $\mathrm{pH}$ meter.

\subsubsection{Preparation of Cross-Linked Formulations and Viscosity Measurements}

Borax or sodium borate which is commonly used for guar gum cross-linking was added for preparing cross-linking formulations. Depending on the concentration of guar, certain amount of saturated borate solution (borax mixed in deionized water) was found sufficient for cross-lining the $200 \mathrm{ml}$ pre-crosslinked guar solution prepared in previous step. The solution was constantly stirred with a whisk whilst borate was being added to ensure even distribution of the cross-linker. This results in a cross-linked formulation.

Viscosities of cross-linked formulations were then measured with the rotating viscometer at room temperature. The use of available rotational viscometer for viscosity measurements of highly viscous cross-linked formulations was facilitated via placement of a custom cap at the bottom of the rotating cylinder of the viscometer. The use of a different size bob (R1B2) which was a non-rotating part of the rotational viscometer enabled the measurement of viscosity of cross-linked formulation at three different but low (10, 30, and 60 RPMs) speeds. The rotational speeds and corresponding shear rates are given in Table 3 . To obtain a reasonable estimate of the viscosity of cross-linked formulations, measurements were repeated for three times. For each test, run at different RPMs, 40-50 grams of cross-linked formulation was weighed out and placed in rotating capped part to measure viscosity. A fresh sample was used for each test from the initially prepared $200 \mathrm{~mL}$ cross-linked formulation as shear history has an effect on viscosity of these formulations.

Table 3. Corresponding shear rates $\left(\mathrm{sec}^{-1}\right)$ at various rotational speeds of digital rotational viscometer

\begin{tabular}{ccc}
\hline & $\begin{array}{c}\text { BOB-R1B1 for Hydrated } \\
\text { (pre-crosslinking) Formulations }\end{array}$ & $\begin{array}{c}\text { BOB-R1B2 for } \\
\text { Cross-linked Formulations }\end{array}$ \\
\hline Viscometer Speed & Shear Rate $\left(\mathrm{sec}^{-1}\right)$ & Shear Rate $\left(\mathrm{sec}^{-1}\right)$ \\
10 RPM & - & 3.77 \\
30 RPM & - & 11.31 \\
60 RPM & 102.1 & 22.62 \\
300 RPM & 510.7 & - \\
600 RPM & 1021.4 & - \\
\hline
\end{tabular}

\subsubsection{Breaking of Cross-Linked Formulations or Cross-Linking Reversal at Elevated Temperature}

Its visualization, and viscosity measurements of resultant fluid at elevated temperature

A new type of commercially available enzyme breaker was then utilized to break the cross-linked formulations at elevated temperatures of up to $85^{\circ} \mathrm{C}\left(185^{\circ} \mathrm{F}\right)$. This enzyme breaker also comes in encapsulated form for a time delayed release, if needed.

On completion of a fracturing job (i.e. creation of fractures by pumping of cross-linked fracturing fluid formulation carrying proppant), fracturing fluid formulation that occupies the newly created void space (fractures) starts to experience near or equal temperature as the actual reservoir temperature. Therefore, efficacy of enzyme breaker in breaking (or cross-linking reversal) cross-linked formulations was required to be observed at elevated temperatures up to $85^{\circ} \mathrm{C}\left(185^{\circ} \mathrm{F}\right)$. As maximum allowable temperature for available digital rotational viscometer was $85^{\circ} \mathrm{C}\left(185^{\circ} \mathrm{F}\right)$, breaking behavior visualization experiments and viscosity measurements of 
resulted solutions were limited to this temperature.

For breaking behavior experiment, $200 \mathrm{~mL}$ of cross-linked formulation (example shown in Figure 3) was placed in a glass beaker and slowly heated using a hot plate. For observing temperature rise of the solution, a thermocouple was held in contact with the formulation. Once the formulation attained the set temperature of $85^{\circ} \mathrm{C}\left(185^{\circ} \mathrm{F}\right)$, breaker, in recommended concentration, was slowly added to the heated formulation. The solution was kept at set temperature until breaking had stopped (by visual inspection) or, in other words, cross-linking was substantially reversed with leaving little cross-linked residue. The resulted formulation (water like) was then transferred to viscometer's heat cup for measuring its viscosity at $85^{\circ} \mathrm{C}\left(185^{\circ} \mathrm{F}\right)$. A fresh sample was used for each viscosity test run. The $\mathrm{pH}$ of water like solution was measured once it cooled to the room temperature.

\section{Results and Discussion}

Table 4 provides the average viscosities of different formulations measured at room temperature and various shear rates after pre-crosslinking hydration. The observed trends in viscosity variation at shear rates (i.e. viscosity measured at different viscometer speeds) are plotted in Figures 5(a) to 9(a). The viscosities (with no shear history) of different cross-linked formulations, measured at room temperature, are given in Table 5. The observed trends in viscosity variation at different shear rates are plotted in Figures 5(b) to 9(b).

\subsection{Pre-Crosslinking Hydration and Cross-Linking Behaviors}

As it can be seen from Figures 5(a) to 9(a), the brine chemistry appeared to play a role in pre-crosslinking hydration of guar gum especially at low guar-gum concentration $(0.30 \%$ by mass or $25 \mathrm{lbs}$ guar/1000 gallons of water). Water chemistry of Brine $\mathrm{H}$ appears to be most amenable to pre-crosslinking hydration as it resulted in highest measured viscosities (Figure 5(a)) for the lowest guar gum concentration tested. As the guar gum concentration increases, the effect of water chemistry on pre-crosslinking hydration appears to vanish. However, it is still visible at low shear rate as evident from large variation in measured viscosity values at a shear rate of $102.1 \mathrm{sec}^{-1}$ for all of the formulations. Prior to mixing guar in a particular synthetic base fluid, its $\mathrm{pH}$ was also measured at room temperature. The measured base fluids' $\mathrm{pH}$ values varied from 7.4 (Brine $\mathrm{H}$ ) to 8.7 (Brine E).

Compared to pre-crosslinked formulations where viscosity measurements were conducted at significantly higher shear rates ranging from $102.1 \mathrm{sec}^{-1}$ to $1021.4 \mathrm{sec}^{-1}$, cross-linked formulations, due to their highly viscous nature, were subjected to significantly lower shear rates in the range from of $3.77 \mathrm{sec}^{-1}$ to $22.62 \mathrm{sec}^{-1}$. This was done to simulate real case scenario where cross-linked fracturing fluid carrying proppant is pumped downhole slowly thus experiencing a low shear regime during pumping operation. Also, viscosity measurements for cross-linked formulations did not take more than a minute at a given shear rate. Hence, it is reasonable to state that the formulation was not exposed to given a shear for long duration while measuring its viscosity at a given shear rate.

As can be seen from Figures 8(b) and 9(b), all of the tested formulations showed similar cross-linking tendencies suggesting that water chemistry did not have a significant effect on cross-linking effect when guar gum concentrations were high $(0.54 \%$ by mass or equivalent to $45 \mathrm{lbs}$ guar/1000 gallons of water or higher). However, as evident from measured viscosity data, effect of water chemistry on cross-linking appeared to be more pronounced when formulations were subjected to low shear rates $\left(3.77 \mathrm{sec}^{-1}\right.$ and $\left.11.31 \mathrm{sec}^{-1}\right)$.

At low guar gum concentrations $(0.42 \%$ by mass or equivalent to $35 \mathrm{lbs} / 1000$ gallons of water or less), cross-linked formulations prepared using $2 \% \mathrm{KCl}$ appeared to achieve superior cross-linking compared to any other base fluids (Figures 5(b) and 6(b)). However, both the low TDS (Brine E) and high TDS (Brine H) seemed to perform best when guar gum concentration was $0.54 \%$ by mass (equivalent to $45 \mathrm{lbs} / 1000$ gallons of water) and when subjected to low shear rates ranging from $3.77 \mathrm{sec}^{-1}$ to $11.31 \mathrm{sec}^{-1}$. High TDS (Brine H) seemed to perform best at lowest guar gum concentration $(0.30 \%$ by mass or equivalent to $25 \mathrm{lbs}$ guar/1000 gallons of water) and entire shear rate range of $3.77 \mathrm{sec}^{-1}$ to $22.62 \mathrm{sec}^{-1}$.

Table 4. Measured average viscosities (room temperature) of hydrated (pre-crosslinking) formulations

\begin{tabular}{ccccc}
\cline { 2 - 5 } Shear rate $\left(\mathrm{sec}^{-1}\right)$ & \multicolumn{4}{c}{ Average viscosity $(\mathrm{cP})$} \\
\cline { 2 - 5 } & $2 \% \mathrm{KCl}$ & Sea Water & Brine $\mathrm{H}$ & Brine $\mathrm{E}$ \\
\hline Guar concentration: & $0.30 \%$ (by mass) & equivalent to 25 & lbs guar/1000 gallons of water \\
\hline 102.1 & 115.1 & 121.6 & 101.4 & 94.0 \\
510.7 & 33.2 & 34.9 & 59.6 & 36.5 \\
1021.4 & 18.3 & 19.6 & 36.6 & 19.1 \\
\hline
\end{tabular}




\begin{tabular}{ccccc}
\hline Guar concentration: $0.42 \%$ (by mass) & equivalent to $35 \mathrm{lbs}$ guar/1000 gallons of water \\
\hline 102.1 & 145.1 & 141.3 & 140.8 & 174.2 \\
510.7 & 44.3 & 46.4 & 50.1 & 44.1 \\
1021.4 & 23.6 & 27.7 & 27.2 & 27.0 \\
\hline Guar concentration: & $0.54 \%$ (by mass) & equivalent to 45 lbs guar/1000 gallons of water \\
\hline 102.1 & 271.5 & 187.5 & 167.2 & 268.1 \\
510.7 & 88.9 & 63.7 & 75.4 & 92.3 \\
1021.4 & 54.1 & 36.8 & 42.5 & 54.5 \\
\hline Guar concentration: $0.65 \%$ (by mass) equivalent to 55 lbs guar/1000 gallons of water \\
\hline 102.1 & 350.8 & 337.0 & 459.8 & 340.4 \\
510.7 & 125.4 & 122.7 & 155.1 & 170.5 \\
1021.4 & 73.2 & 74.8 & 82.2 & 68.8 \\
\hline Guar concentration: $0.84 \%$ (by mass) equivalent to 70 lbs guar/1000 gallons of water \\
\hline 102.1 & 710.2 & 783.1 & 948.2 & 995.8 \\
510.7 & 239.2 & 248.3 & 285.4 & 297.1 \\
1021.4 & 132.1 & 137.1 & 159.0 & 167.4 \\
\hline \multicolumn{5}{c}{} \\
\hline
\end{tabular}

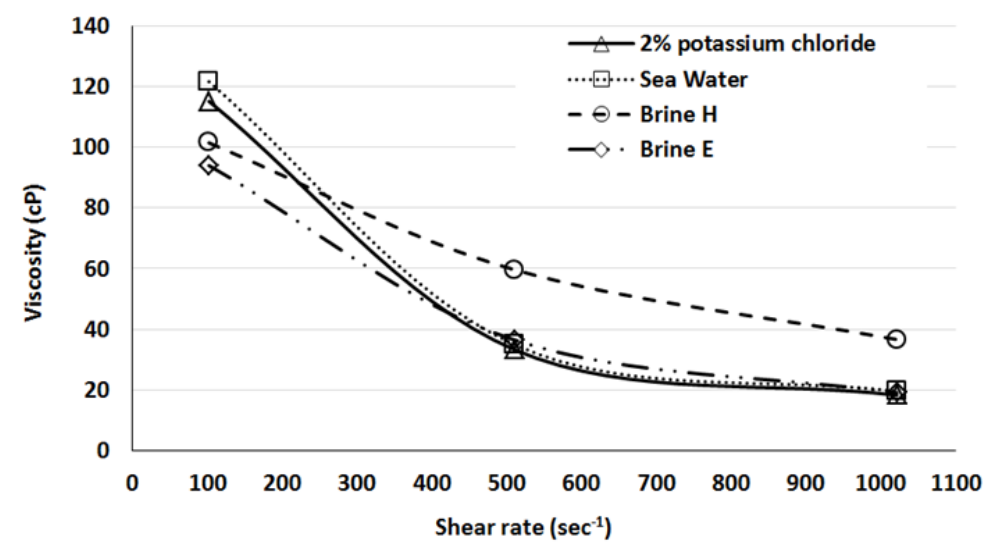

(a)

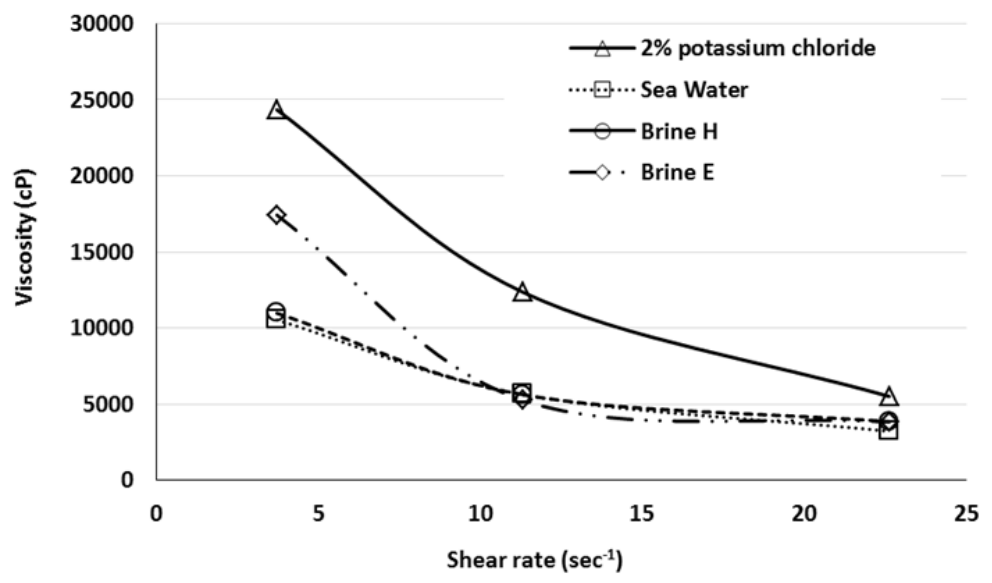

(b)

Figure 5. Average viscosities of (a) hydrated (pre-crosslinking); (b) cross-linked fracturing fluid formulations containing $0.30 \%$ (by mass) guar gum (equivalent to $25 \mathrm{lbs}$ guar per 1000 gallons of water) at different shear rates 


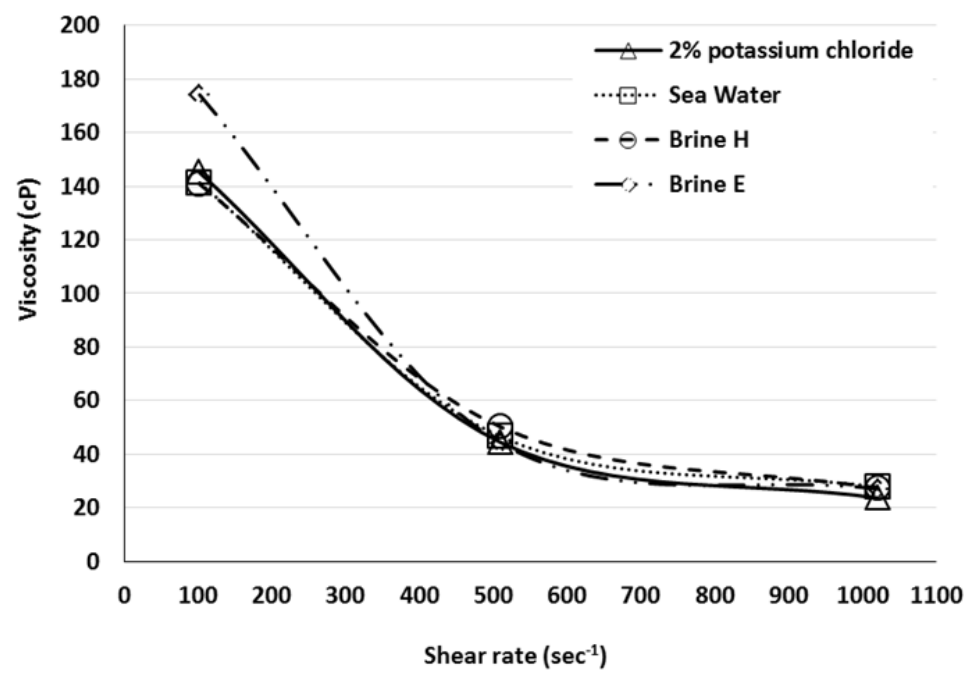

(a)

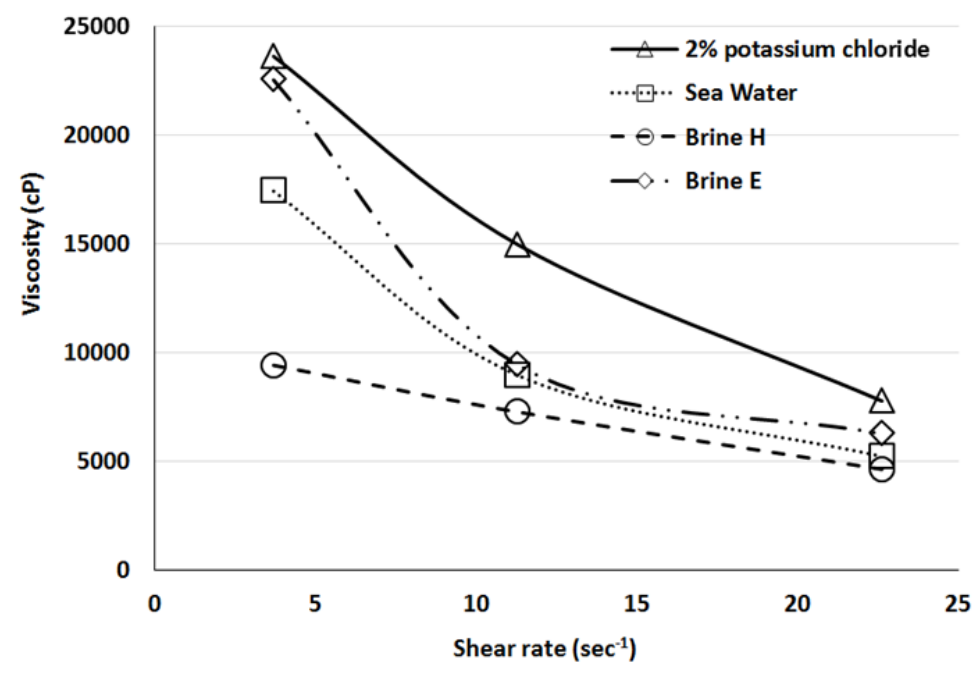

(b)

Figure 6. Average viscosities of (a) hydrated (pre-crosslinking); (b) cross-linked fracturing fluid formulations containing $0.42 \%$ (by mass) guar gum (equivalent to $35 \mathrm{lbs}$ guar per 1000 gallons of water) at different shear rates

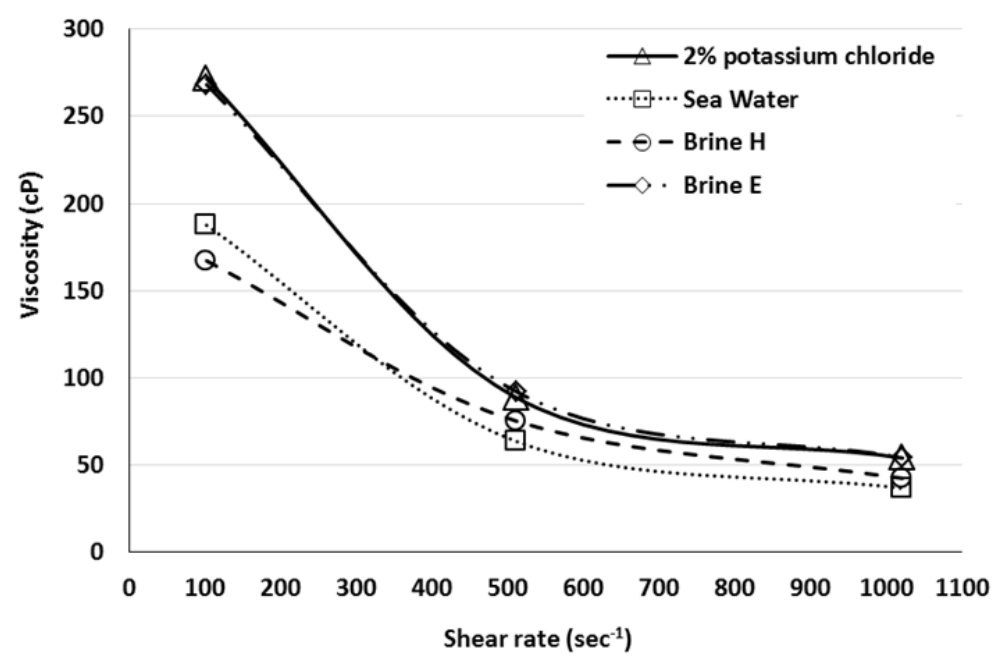

(a) 


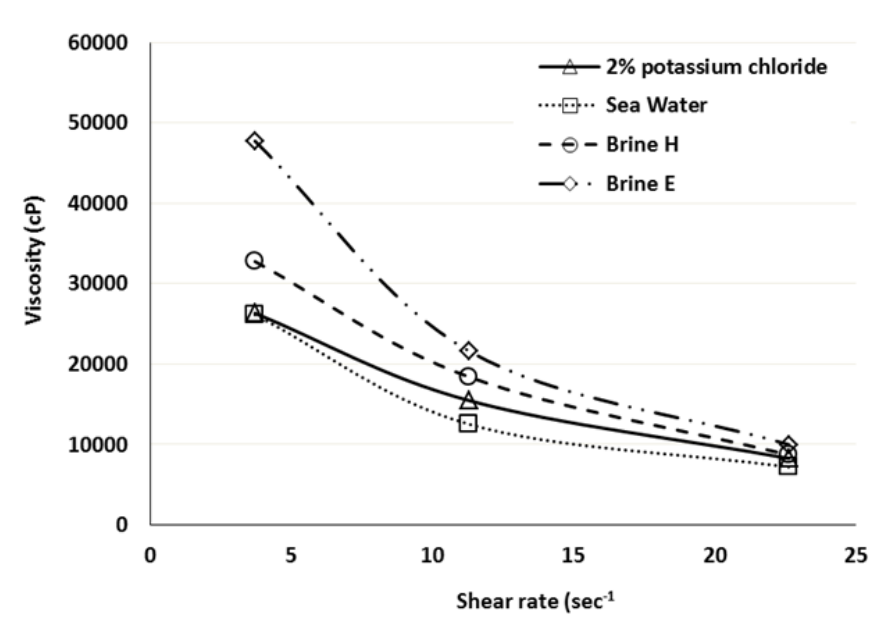

(b)

Figure 7. Average viscosities of (a) hydrated (pre-crosslinking); (b) cross-linked fracturing fluid formulations containing $0.54 \%$ (by mass) guar gum (equivalent to $45 \mathrm{lbs}$ guar per 1000 gallons of water) at different shear rates

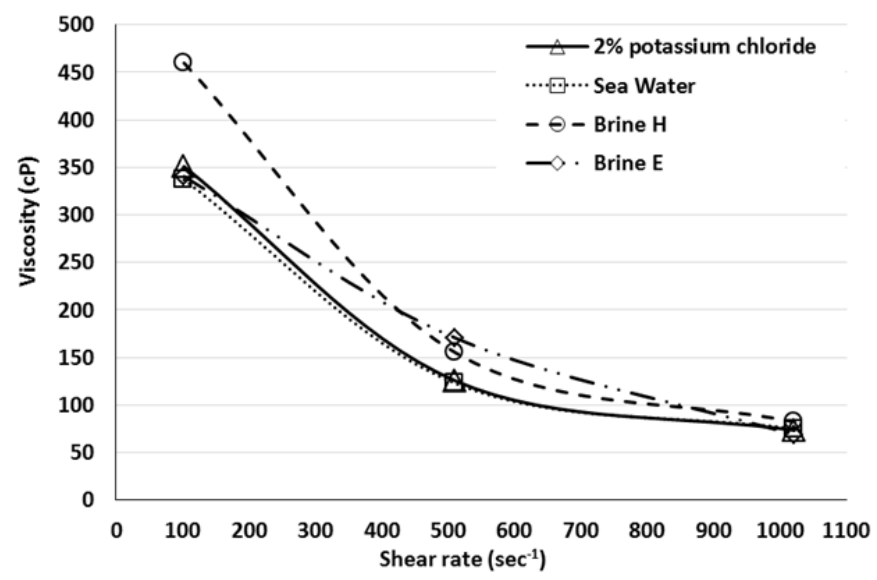

(a)

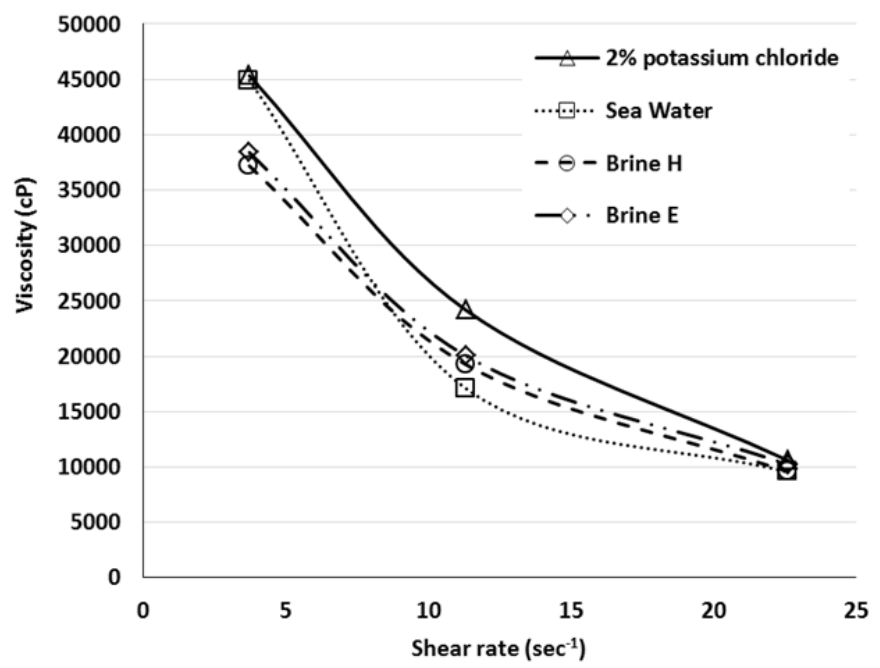

(b)

Figure 8. Average viscosities of (a) hydrated (pre-crosslinking); (b) cross-linked fracturing fluid formulations containing $0.65 \%$ (by mass) guar gum (equivalent to $55 \mathrm{lbs}$ guar per 1000 gallons of water) at different shear rates 


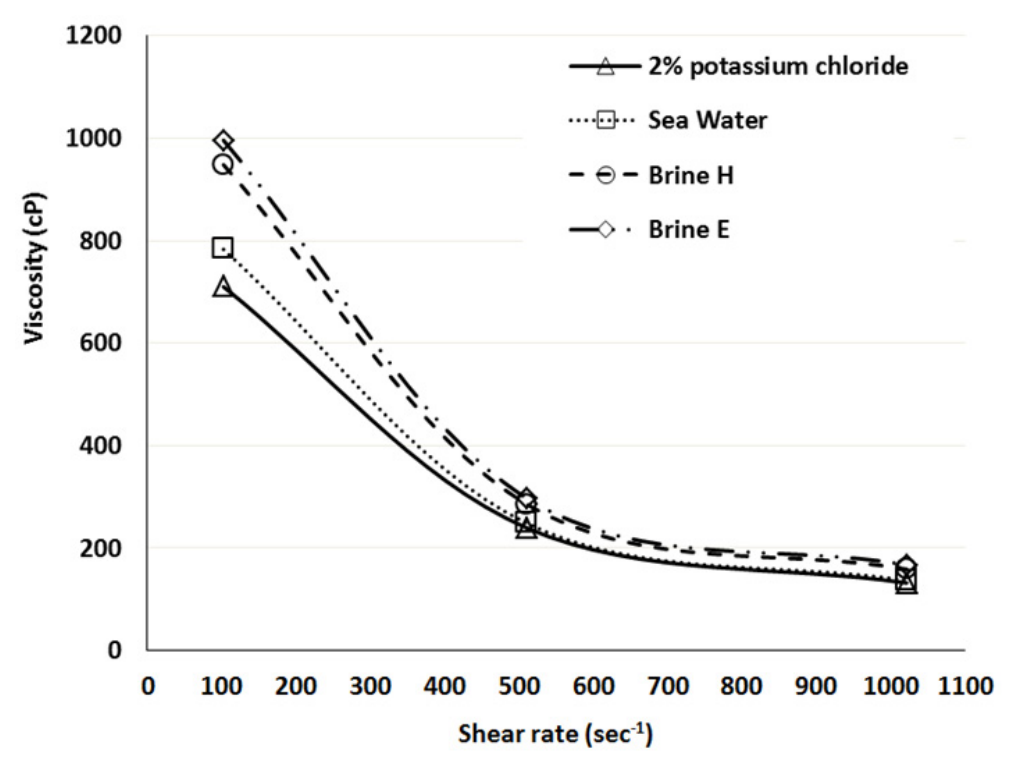

(a)

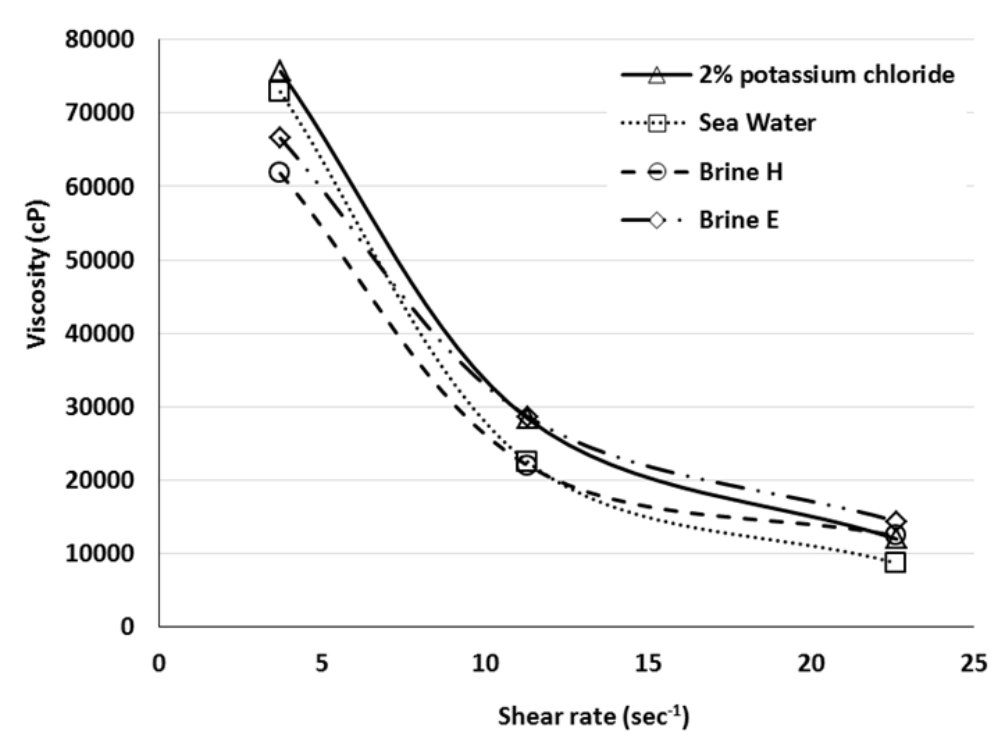

(b)

Figure 9. Average viscosities of (a) hydrated (pre-crosslinking); (b) cross-linked fracturing fluid formulations containing $0.84 \%$ (by mass) guar gum (equivalent to $70 \mathrm{lbs}$ guar per 1000 gallons of water) at different shear rates

Table 5. Measured average viscosities (room temperature) of cross-linked formulations

\begin{tabular}{|c|c|c|c|c|}
\hline \multirow[b]{2}{*}{ Shear rate $\left(\mathrm{sec}^{-1}\right)$} & \multicolumn{4}{|c|}{ Average viscosity $(\mathrm{cP})$} \\
\hline & $2 \% \mathrm{KCl}$ & Sea Water & Brine $\mathrm{H}$ & Brine $\mathrm{E}$ \\
\hline \multicolumn{5}{|c|}{ Guar concentration: $0.30 \%$ (by mass) equivalent to $25 \mathrm{lbs}$ guar $/ 1000$ gallons of water } \\
\hline 3.71 & 24338.4 & 10529.0 & 10973.4 & 17418.4 \\
\hline 11 & & & & 5246.6 \\
\hline 22.62 & 5507.0 & 3215.7 & 3850.7 & 3825.2 \\
\hline \multicolumn{5}{|c|}{ Guar concentration: $0.42 \%$ (by mass) equivalent to $35 \mathrm{lbs}$ guar $/ 1000$ gallons of water } \\
\hline 3.71 & 23615.8 & 17413.5 & 9401.7 & 22525.7 \\
\hline 11.31 & 149 & 89. & 72 & 9409.0 \\
\hline 22.62 & 7758.0 & 5209.7 & 4616.2 & 6247.0 \\
\hline
\end{tabular}




\begin{tabular}{ccccc}
3.71 & 26330.6 & 26130.9 & 32755.5 & 47732.2 \\
11.31 & 15454.6 & 12508.6 & 18384.6 & 21579.3 \\
22.62 & 8278.7 & 7219.2 & 8721.0 & 9999.0 \\
\hline Guar concentration: $0.65 \%$ (by mass) & equivalent to 55 lbs guar/1000 gallons of water \\
\hline 3.71 & 45341.9 & 44911.7 & 37189.2 & 38405.1 \\
11.31 & 24171.0 & 17095.8 & 19252.7 & 20039.6 \\
22.62 & 10592.0 & 9540.5 & 9586.3 & 10247.4 \\
\hline \multicolumn{4}{l}{ Guar concentration: $0.84 \%$ (by mass) } & equivalent to 70 lbs guar/1000 gallons of water \\
\hline 3.71 & 75675.8 & 72869.9 & 61774.0 & 66575.1 \\
11.31 & 28367.7 & 22460.4 & 21979.4 & 28642.9 \\
22.62 & 12008.1 & 8717.2 & 12433.7 & 14411.5 \\
\hline
\end{tabular}

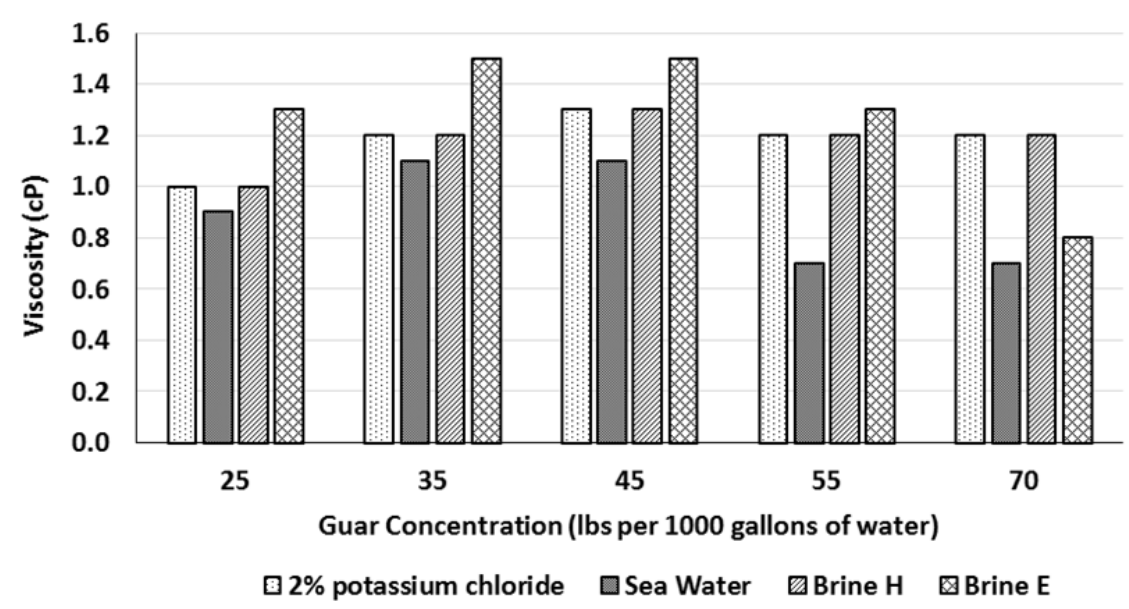

Figure 10. Post-breaking viscosities of different formulations in the presence of a new type of commercially available enzyme breaker (measured at $85^{\circ} \mathrm{C}\left(185^{\circ} \mathrm{F}\right)$ )

\subsection{Breaking Behavior of Cross-Linked Formulations in Presence of New Type of Enzyme Breaker}

As can be seen from Figure 10, measured viscosities of post-breaking formulations at elevated temperature of $85^{\circ} \mathrm{C}\left(185^{\circ} \mathrm{F}\right)$ found to vary from $0.7 \mathrm{cp}$ to $1.7 \mathrm{cp}$. These results clearly demonstrate that the new type of commercially available enzyme breaker was able to efficiently reverse the cross-linking of guar gum-based fracturing fluid formulations tested here. Water chemistry appeared to have limited effect on the performance of tested enzyme breaker; however, guar gum concentration seemed to have some effect on the stability of cross-linked formulations itself. The cross-linked formulations containing low guar concentrations ( 25 and $35 \mathrm{lbs}$ guar/ 1000 gallons of water) started to break themselves at temperatures above $60^{\circ} \mathrm{C}\left(140^{\circ} \mathrm{F}\right)$ whereas high concentration formulations $(45,55$, and $70 \mathrm{lbs}$ guar/1000 gallons of water) sustained the crosslinking abilities at temperatures up to $85^{\circ} \mathrm{C}\left(185^{\circ} \mathrm{F}\right)$. Once enzyme breaker was added, all of the cross-linked formulations were effectively broken and turned in to water like solution leaving little residue (i.e. cross-linked formulation).

The breaking time varies from 15 to 45 minutes for cross-linked formulations containing lower guar concentrations $(0.54 \%$ by mass or equivalent to $45 \mathrm{lbs}$ guar/ 1000 gallons of water or less) whereas cross-linked formulations containing high guar concentrations $(0.65 \%$ by mass or equivalent to $55 \mathrm{lbs}$ guar/1000 gallons of water or higher) took 60 mins to 92 mins before no more breaking could be visually observed.

The $\mathrm{pH}$ values of post-breaking solutions were also measured after cooling them down to room temperature. The measured $\mathrm{pH}$ values were found to be in the range from 7.8 to 8.7 . It is noted here that measured $\mathrm{pH}$ of enzyme breaker solution at room temperature was found to be 6.0 .

\section{Summary and Conclusions}

The results suggest that water chemistry has limited effect on the viscosity of water-based (associated water or sea water) fracturing fluid formulations prepared via cross-linking of guar by borate. However, guar gum concentration was found to affect the breaking behaviors of the fracturing fluid formulations tested in this study.

The results presented in this study suggested that $2 \% \mathrm{KCl}$ appeared to achieve superior cross-linking compared to other base fluids at low guar gum concentrations $(0.42 \%$ by mass or equivalent to $35 \mathrm{lbs}$ guar/ 1000 gallons of 
water or less). However, both the low TDS (Brine E) and high TDS (Brine H) brine solutions performed the best when guar gum concentration was $0.54 \%$ by mass (equivalent to $45 \mathrm{lbs}$ guar/1000 gallons of water) and when subjected to low shear rates $\left(3.77 \mathrm{sec}^{-1}\right.$ and $\left.11.31 \mathrm{sec}^{-1}\right)$. The new type of commercially available enzyme breaker was found to be effective in breaking the tested cross-linked formulations at elevated temperature (as high as $\left.85^{\circ} \mathrm{C}\left(185^{\circ} \mathrm{F}\right)\right)$.

Both crosslinking and breaking behaviors of associated water- or sea water-based fracturing fluid formulations tested in the study were found more or less comparable to the behaviors of standard cross-linked formulation (guar gum $+2 \% \mathrm{KCl}$ ). These results suggest that both the associated water resulting from local conventional oil production operations and sea water could serve as an alternative source of base fluid for use in fracturing jobs.

The potential use of associated water or sea water for preparing guar gum-based fracturing fluid formulations can also assist industry in unlocking the potential of California's Monterey shale resource by conventional fracturing technology in near future without putting significant burden on precious fresh water resources of the region.

To the best of our knowledge, this appears to be first study in which crosslinking and breaking behaviors of associated water or sea water-based fracturing fluid formulations have been evaluated for assessing the potential use of associated water produced with conventional oil and gas production operations in the Kern County of California for use in fracturing jobs. The results presented here are encouraging however the effect of other frequently used additives on the crosslinking and breaking behaviors of guar gum-based fracturing fluid formulations (studied here) should also be taken into the consideration while designing a fracturing job involving the use of associated water or sea water as base fluid.

\section{Acknowledgements}

Help of several undergraduate students namely Antonio Rosas, Daryl Trudeau, and Laura Alvarez with laboratory experimentations is greatly appreciated. These students are currently pursuing their B.S. in engineering sciences degree with petroleum engineering emphasis at CSUB. Authors also thank to Mr. Shrinidhi Shetty, former lecturer of petroleum engineering at CSUB, for his constructive remarks and help with manuscript preparation.

\section{References}

Al-Kanaan, A., Rahim, Z., \& Al-Anazi, H. (2013). Selecting Optimal Fracture Fluids, Breaker System, and Proppant Type for Successful Hydraulic Fracturing and Enhanced Gas Production - Case Studies. Society of Petroleum Engineers. http://dx.doi.org/10.2118/163976-MS

Barati, R., \& Liang, J. T. (2014). A Review of Fracturing Fluid Systems Used for Hydraulic Fracturing of Oil and Gas Wells. Journal of Applied Polymer Science. http://dx.doi.org/10.1002/app.40735

CA FRACKFACTS Website (2015). http://www.cafrackfacts.org/impacts/water/

California Council on Science and Technology, Lawrence Berkeley National Laboratory, and Pacific Institute (2014). Advanced Well Stimulation Technologies in California: An Independent Review of Scientific and Technical Information. Retrieved from http://ccst.us/BLMreport

Carroll, R. (2015). California used 70 million gallons of water in fracking in 2014. Retrived from http://www.reuters.com/article/us-california-drought-fracking-exclusive-idUSKBN0MU01M20150403

DOGGR. (2015). Online database and brine chemistry reports. Retrived from http://www.conservation.ca.gov/dog/pubs_stats/annual_reports/Pages/annual_reports.aspx

EOG Resources Website (2015). Water Management. Retrived from http://www.eogresources.com/responsibility/water_management.html

Freyman, M. (2014). Hydraulic Fracturing \& Water Stress: Water Demand by the Numbers-Shareholder, Lender \& Operator Guide to Water Sourcing. Report published by Ceres. Retrived from http://www.ceres.org/resources/reports/hydraulic-fracturing-water-stress-water-demand-by-the-numbers/vie $\mathrm{w}$

Gallegos, T. J., \& Varela, B. A. (2015). Trends in Hydraulic Fracturing Distributions and Treatment Fluids, Additives, Proppants, and Water Volumes Applied to Wells Drilled in the United States from 1947 Through 2010 - Data Analysis and Comparison to the Literature. U.S. Geological Survey Scientific Investigations Report, 2014(5131), p15. http://dx.doi.org/10.3133/sir20145131

Kyaw, A., Azahar, B. S. B. N., \& Tunio, S. Q. (2012). Fracturing Fluid (Guar Polymer Gel) Degradation Study 
by using Oxidative and Enzyme Breaker. Research Journal of Applied Sciences, Engineering and Technology, 4(12), 1667-1671. ISSN: 2040-7467. Retrived from http://maxwellsci.com/print/rjaset/v4-1667-1671.pdf

Long, J. C. S., Feinstein, L. C., Birkholzer, J., Jordan, P., Houseworth, J., Dobson, P. F., Heberger, M., \& Gautier, D. L. (2015). An Independent Scientific Assessment of Well Stimulation in California, Volume I: Well Stimulation Technologies and their Past, Present, and Potential Future Use in California. Report published by the California Council on Science and Technology. ISBN Number: 978-1-930117-97-6.

Mantell, M.E. (2011). Produced Water Reuse and Recycling Challenges and Opportunities across Major Shale Plays. Retrived from http://www.epa.gov/sites/production/files/documents/09_Mantell___Reuse_508.pdf

Montgomery, C. (2013). Fracturing Fluid Components in Andrew P. Bunger, John McLennan, and Rob Jeffrey (Eds.). Effective and Sustainable Hydraulic Fracturing. ISBN 978-953-51-1137-5. Retrived from http://www.intechopen.com/books/effective-and-sustainable-hydraulic-fracturing/fracturing-fluid-compone nts

Pike, M. (2003). Fracturing Fluid Properties. $\quad$ Retrived from http://www.trican.ca/pdf/services_technology/tech_papers/FracFluid_Properties.pdf

Qingdao Lead Oilfield Solutions Co., Ltd (Refer to as L.E.A.D.) website (2015). http://www.sloilfield.com/Enzyme-Breaker_1226.html

Robert, M., \& Pin, T. J. (1993). Enzyme Breaker for Galactomannan Based Fracturing Fluid. USA Patent 5201370, 13 April.

Sieminski, A. (2014). Outlook for U.S. Oil and Gas [PowerPoint slides]. Retrived from http://www.eia.gov/pressroom/presentations/sieminski_01042014.pdf

U.S. EPA (2015). Analysis of Hydraulic Fracturing Fluid Data from the FracFocus Chemical Disclosure Registry 1.0. Office of Research and Development, Washington, DC. EPA/601/R-14/003.

Vo, L. K., Sparks, B., Parton, C., Cortez, J., \& Tanner, G. T. (2014). Novel Low-Residue High Brine Fracturing Fluid. Paper prepared for presentation at the 2014 AADE Fluids Technical Conference and Exhibition held at the Hilton Houston North Hotel, Houston, Texas, April 15-16. Paper no. AADE-14-FTCE-36.

Wasylishen, R., \& Sarah, F. S. (2012). Reuse of Flowback \& Produced Water for Hydraulic Fracturing in Tight Oil. Report prepared for the Petroleum Technology Alliance Canada (PTAC). Retrived from http://www.ptac.org/attachments/561/download

WSPA. (2015). Setting the Record Straight: Water and Hydraulic Fracturing in California. Retrived from https://www.wspa.org/sites/default/files/uploads/Setting_Record_Straight_Water.pdf

\section{Copyrights}

Copyright for this article is retained by the author(s), with first publication rights granted to the journal.

This is an open-access article distributed under the terms and conditions of the Creative Commons Attribution license (http://creativecommons.org/licenses/by/3.0/). 